\title{
Substrate Temperature in Plastic and Alternative Nursery Containers
}

\author{
Susmitha Nambuthiri ${ }^{1,7,14}$, Robert L. Geneve ${ }^{1,8}$, Youping Sun ${ }^{2,9}$, \\ Xueni Wang ${ }^{3,10}$, R. Thomas Fernandez ${ }^{3,11}$, Genhua Niu ${ }^{4,11}$, \\ Guihong Bi ${ }^{5,12}$, and Amy Fulcher 6,13
}

\begin{abstract}
ADDITIONAL INDEX WORDs. biocontainer, coir fiber, keratin, wood pulp,
\end{abstract} sustainability

SuMmary. The green industry has identified the use of biodegradable containers as an alternative to plastic containers as a way to improve the sustainability of current production systems. Field trials were conducted to evaluate the performance of four types of 1-gal nursery biocontainers [keratin (KR), wood pulp (WP), fabric (FB), and coir fiber (Coir)] in comparison with standard black plastic (Plastic) containers on substrate temperature, water use, and biomass production in aboveground nurseries. Locations in Kentucky, Michigan, Mississippi, and Texas were selected to conduct experiments during May to Oct. 2012 using 'Green Velvet' boxwood (Buxus sempervirens $\times$ B. microphylla) and 'Dark Knight' bluebeard (Caryopteris $\times$ clandonensis) in 2013. In this article, we were focusing on the impact of alternative container materials on hourly substrate temperature variations and plant growth. Substrate temperature was on an average higher (about $6^{\circ} \mathrm{C}$ ) in Plastic containers (about $36^{\circ} \mathrm{C}$ ) compared with that in WP, FB, and Coir containers. However, substrate temperature in KR containers was similar to Plastic. Substrate temperature was also influenced by local weather conditions with the highest substrate temperatures recorded in Texas followed by Kentucky, Mississippi, and Michigan. Laboratory and controlled environment trials using test containers were conducted in Kentucky to evaluate sidewall porosity and evaporation loss to confirm field observations. Substrate temperature was similar under laboratory simulation compared with field studies with the highest substrate temperature observed in Plastic and KR, intermediate in WP and lowest in FB and Coir. Side wall temperature was higher in Plastic, KR, and FB compared with WP and Coir, while side wall water loss was greatest in FB, intermediate in WP and Coir, and lowest in plastic and KR. These observations suggest that the contribution of sidewall water loss to overall container evapotranspiration has a major influence on reducing substrate temperature. The porous nature of some of the alternative containers increased water use, but reduced heat stress and enhanced plant survival under hot summer conditions. The greater drying rate of alterative containers especially in hot and dry locations could demand increased irrigation volume, more frequent irrigation, or both, which could adversely affect the economic and environmental sustainability of alternative containers.

$\mathrm{L}$

arge-scale container-grown nursery plant production began in the early 1950s and helped to diversify the nursery industry. Most of the clay, recycled metal, and wooden containers initially used in nurseries were replaced by plastic containers in the 1960s, and container production systems became more abundant because of ease of transplanting and year-round production and/or sales (Davidson et al., 1988). Plastic has remained as the most common material for nursery containers but due to economic and environmental considerations such as price fluctuations, high collection and sanitation costs, and chemical contamination concerns; used plastic containers are primarily disposed of in landfills (Garthe and Kowal, 1993; Hall et al., 2010; Helgeson et al., 2009) and given limited access to recycling centers enhanced interest in alternative containers (Fulcher et al., 2013). Green industry stakeholders (i.e., nursery, greenhouse, and landscape professionals) have identified the use of plantable, compostable, or recyclable containers as an alternative way to improve the sustainability of current production systems (Nambuthiri et al., 2015).

Container materials and colors can affect plant growth by modifying substrate temperature and the water budget (Markham et al., 2011). Heat energy enters the production system from direct and reflected solar radiation. Containers act as a solar collector in the system, as does the exposed substrate surface (Martin and Ingram, 1992). Excessive substrate heating occurs due to absorption of solar radiation and lack of heat dissipation from the nonporous black plastic containers (Beattie et al., 1987). These conditions will result in changes to the root environment and may influence plant growth and productivity. A major concern for growing plants under full sun in plastic containers is the substrate temperature, which can injure roots if it exceeds $40^{\circ} \mathrm{C}$ for several hours (Mathers, 2003; Ruter and Ingram, 1990). Heat is transferred to the substrate in the container primarily through conduction and lost to the external environment via convection. Martin and Ingram (1992) developed simulation models to study substrate temperature and found that properties such as color, porosity, reflectivity of container surface (albedo), thermal conductivity of the container, thermal exchange between the container sidewall and the growing substrate, and the surrounding environment can influence substrate temperature.

Supraoptimal substrate temperatures that are sublethal cause indirect injuries such as loss of plant vigor, nutritional disorders, increased susceptibility to diseases and other anomalies with plant developmental characteristics (Ingram et al., 1986a). Root zone temperature greater than $40{ }^{\circ} \mathrm{C}$ suppresses plant growth and quality from direct and indirect temperature effects (Ingram et al., 1986b). Many researchers have observed the deleterious effects of high rhizosphere

\begin{tabular}{llll}
\hline $\begin{array}{l}\text { Units } \\
\begin{array}{l}\text { To convert U.S. to SI, } \\
\text { multiply by }\end{array}\end{array}$ & U.S. unit & SI unit & $\begin{array}{l}\text { To convert SI to U.S., } \\
\text { multiply by }\end{array}$ \\
\hline 29.5735 & $\mathrm{fl} \mathrm{oz}$ & $\mathrm{mL}$ & 0.0338 \\
0.3048 & $\mathrm{ft}$ & $\mathrm{m}$ & 3.2808 \\
0.0929 & $\mathrm{ft}^{2}$ & $\mathrm{~m}^{2}$ & 10.7639 \\
3.7854 & $\mathrm{gal}$ & $\mathrm{L}$ & 0.2642 \\
2.54 & inch $(\mathrm{es})$ & $\mathrm{cm}^{3}$ & 0.3937 \\
1.7300 & $\mathrm{Oz} / \mathrm{inch}^{3}$ & $\mathrm{~g} \cdot \mathrm{cm}^{-3}$ & 0.5780 \\
6.8948 & $\mathrm{psi}$ & $\mathrm{kPa}$ & 0.1450 \\
$\left({ }^{\circ} \mathrm{F}-32\right) \div 1.8$ & ${ }^{\circ} \mathrm{F}$ & ${ }^{\circ} \mathrm{C}$ & $\left({ }^{\circ} \mathrm{C} \times 1.8\right)+32$ \\
& & & \\
\hline
\end{tabular}


temperature on photosynthesis and assimilate partitioning (Gosselin and Trudel, 1986), water stress (Ingram et al., 1986a), nutrient deficiencies (Johnson and Ingram, 1984), or impaired plant growth and development (Martin and Ingram, 1988).

One way to deal with heat stress is to use containers with porous walls to allow evaporation of water from the outer surface, improving heat exchange between the substrate and environment (Bunt and Kulwiec, 1970). Container material composition has been found to influence substrate heat development because of the differing thermal properties of the components (Bunt and Kulwiec, 1971). Any material that reduces absorption of solar radiation and increases exchange of heat in the production system can contribute to reducing supraoptimal substrate temperature. Porous containers (clay, paper, peat, etc.) showed a slower increase in substrate temperature than nonporous (plastic, glass, paraffin-protected, etc.)

\footnotetext{
This project was supported by the USDA National Institute of Food and Agriculture, hatch project numbers KY011032, MICL02010, TEX09045, TEN00406, MIS211090. This research was partially funded by the USDA Specialty Crops Research Initiative Grant number 2010-01190 with matching resources from the University of Arkansas Division of Agriculture; the University of Kentucky College of Agriculture, Food, and Environment; Michigan State University Project GREEEN, and Mississippi State University Agricultural and Forestry Experiment Station, Texas A\&M System, and University of Tennessee.

The authors appreciate the in-kind support of plant materials from Spring Meadow Nursery, Grand Haven, MI, substrate from Renewed Earth LLC, Kalamazoo, MI, and containers from ITML Horticultural Products, Middlefield, $\mathrm{OH}$ and Western Pulp Products Co., Corvallis, OR.

${ }^{1}$ Department of Horticulture, University of Kentucky, Lexington, KY 40546

${ }^{2}$ Landscape Water Conservation, Texas A\&M AgriLife Research and Extension Center, El Paso, TX 79927

${ }^{3}$ Department of Horticulture, A216 Plant \& Soil Science Building, Michigan State University, East Lansing, MI 48824

${ }^{4}$ Landscape Water Conservation, Texas A\&M AgriLife Research and Extension Center, El Paso, TX 79927

${ }^{5}$ Department of Plant and Soil Sciences, Mississippi State University, Mississippi State, MS 39762

${ }^{6}$ Sustainable Ornamental Plant Production and Landscape Management, University of Tennessee, Knoxville, TN 37996

${ }^{7}$ Postdoctoral Researcher

${ }^{8}$ Professor

${ }^{9}$ Research Associate

${ }^{10}$ Graduate Research Assistant

${ }^{11}$ Associate Professor

${ }^{12}$ Associate Research Professor

${ }^{13}$ Assistant Professor

${ }^{14}$ Corresponding author. E-mail: ssnamb2@uky.edu.
}

containers due to the higher latent heat for vaporization of water (Jones, 1931).

Green industry stakeholders have identified the use of biodegradable container alternatives as a way to improve the sustainability of current production systems (Behe et al., 2013; Dennis et al., 2010; Hall et al., 2010). An online survey showed that consumers were willing to pay a premium for compostable, plantable, and recyclable containers due to their proenvironmental attributes (Khachatryan et al., 2014). Recently, several alternative containers made from WP, paper, coir, rice hulls, peat, bioplastic, recycled plastic have become commercially available (Hall et al., 2010; Nambuthiri et al., 2015) and have been recently evaluated for their suitability for a variety of species and environmental scenarios (Evans and Hensley, 2004; Lopez and Camberato, 2011; Nambuthiri and Ingram, 2014).

This study evaluated the impact of container material on substrate temperature dynamics and sidewall evaporative water loss under laboratory, controlled environment, and in aboveground nursery settings.

\section{Materials and methods}

LABORATORY STUDY. The study was conducted at the University of Kentucky, Lexington, to evaluate the heat flux and substrate temperature as affected by container material. Four types of 1-gal nursery containers with similar container height and diameter were evaluated with five replicates per container type. They included 1) conventional black plastic containers [Plastic (C400; Nursery Supplies, Orange, CA)] and alternative containers, 2) wood pulp [WP (7X7RD; Western Pulp Products Co., Jacksonville, TX)] made from wood pulp, 3) keratin [KR (Horticultural Research Institute, Washington, DC)] made from a chicken feather-based bioplastic, 4) a black fabric container [FB (Root Pouch, Hillsboro, OR)] made from recycled plastic, and 5 ) coir fiber [Coir (Retail Nursery Pot, Markham, ON, Canada)]. The experiment was conducted under standard laboratory conditions with an ambient air temperature of $19 \pm 0.5{ }^{\circ} \mathrm{C}$. The containers were filled with equal volumes of an $85 \%$ pine bark: $15 \%$ Sphagnum peat $(v / v)$ substrate. The substrate was wetted to saturation, mixed thoroughly and allowed to drain before filling each container. The containers were permitted to equilibrate to room temperature for $30 \mathrm{~min}$ before initiating the experiments. Two incandescent (100 W each) bulbs, $\approx 1$ inch apart from each other in a tandem fixture were placed 6 inches away from the container sidewall to provide heating for $90 \mathrm{~min}$. After $90 \mathrm{~min}$, total radiation flux density reflecting from the container wall was measured using a pyranometer (LI-200; LI-COR Biosciences, Lincoln, NE) connected to a data logger (LI-1400, LI-COR Biosciences). After turning the light off, the temperature of the container wall was measured using an IR thermometer (model 42510; Extech Instruments, Nashua, NH) aimed $\approx 3$ inches away from the wall. The wall temperature was measured at 2, 6, and 10 inches, respectively, below the container rim and average wall temperature was calculated. Temperature at 1 -inch depth of the substrate was measured using a digital thermometer (Fisher Scientific, Pittsburgh, PA) at 1 inch from the container wall and at the center of the container ( 2 inches from the container wall).

Controlled environment. Substrate water loss from each type of container was evaluated in a controlled environment chamber with temperature and humidity control (model J4S5580A; Parameter Generation and Control, Black Mountain, NC). The four container types were filled with equal quantities of 85 pine bark: 15 Sphagnum peat (by volume) substrate mix (Renewed Earth, Kalamazoo, MI). Substrate physical properties were as follows: $89.9 \%$ total porosity, $30.7 \%$ available water, $30.6 \%$ unavailable water, $28.6 \%$ air space, and $0.16 \mathrm{~g} \cdot \mathrm{cm}^{-3}$ bulk density. The substrate was wetted to saturation, mixed thoroughly, and allowed to drain before filling each container. The containers were permitted to equilibrate to room temperature for $30 \mathrm{~min}$ before initiating the experiments. An air temperature of $32{ }^{\circ} \mathrm{C}$ and relative humidity of $45 \%$ was maintained inside the control chamber to provide a vapor pressure deficit $\left(\mathrm{VPD}_{\text {air }}\right)$ of $2.6 \mathrm{kPa}$ inside the chamber. The chamber air conditioning system was able to successfully maintain $\mathrm{VPD}_{\text {air }}$ as expected (Fulcher et al., 2011). Containers were either sealed at the top using plastic wrap, and 
drainage holes were sealed using wax to allow loss of water only through the wall or the containers were not sealed to allow evaporative water loss through both top and sidewall. Container weight was recorded hourly for $8 \mathrm{~h}$ until there was no significant weight change. Hourly and cumulative evaporative water loss over $8 \mathrm{~h}$ was calculated. There were five replicates for each type of nursery container. In biocontainers like WP, the initial temperature and water vapor values observed with new containers under laboratory conditions might not reflect their properties in older weathered containers in the field.

Field sTudy. The field study was conducted at university research farms in Michigan (lat. $42.7^{\circ} \mathrm{N}$, long. $84.5^{\circ} \mathrm{E}$, elevation $866 \mathrm{ft}$ ), Kentucky (lat. $38.1^{\circ} \mathrm{N}$, long. $84.5^{\circ} \mathrm{W}$, elevation $1043 \mathrm{ft}$ ), Mississippi (lat. $32.0^{\circ} \mathrm{N}$, long. $90.4^{\circ} \mathrm{W}$, elevation $489 \mathrm{ft}$ ), and Texas (lat. $31.7^{\circ} \mathrm{N}$, long. $106.3^{\circ} \mathrm{W}$, elevation $3737 \mathrm{ft}$ ) during 2012-13. Weather data were obtained from an on-farm weather station at hourly intervals.

'Green Velvet' boxwood in 2012 and 'Dark Knight' bluebeard in 2013 were planted in the 1-gal container types as previously described. The species were selected that would grow over the large variation in climates seen among the study locations and plants that would normally be grown in a l-gal container. The containers were filled with equal quantities of an 85 pine bark:15 sphagnum peat $(\mathrm{v} / \mathrm{v})$ substrate. This one-factor, completely randomized design experiment with three replicates per container type was undertaken from June to Oct. 2012 and May to Oct. 2013. There were 30 plants for each container type arranged in a single block at a l-ft spacing on-center with guard rows surrounding all treatment plants. Two containers on the south side of the block were evaluated for temperature and data were collected from three replicated blocks. Two thermocouples (Type T copper-constantan thermocouple wires; Omega Engineering, Stamford, CT) or thermistors (107-LC; Campbell Scientific, Logan, UT) in each plot measuring substrate temperature were placed in the container at 1 inch below the substrate surface and at 1 inch from the southfacing side. Data were recorded using a data logger (CR1000, Campbell
Scientific) programmed to scan every $30 \mathrm{~s}$ and to determine hourly maxima, minima, and average.

Substrate moisture levels were measured and controlled using dielectric capacitance sensors (ECHO-5; Decagon Devices, Pullman, WA) that were completely inserted at $45^{\circ}$ angle into the center of two containers per irrigation zone and were connected to the same data logger that recorded substrate temperature. The data logger was attached to a multiplexer (AM16/32, Campbell Scientific) and a 16-channel relay controller (SDM-CDl6AC, Campbell Scientific) to operate solenoid valves. Volumetric water content values were calculated from $\mathrm{mV}$ output and sensor-specific calibration equations in the program (not presented). One capacitance sensor per container was installed halfway between the base of the plant and the container sidewall. All plants were irrigated at 0700 and $1900 \mathrm{HR}$ to replace $100 \%$ water use (Warsaw et al., 2009) calculated based on the average soil moisture readings of the two ECHO-5 probes per plot.

Data Analysis. Analysis of variance was performed using PROC GLM procedure of SAS (version 9.1.3; SAS Institute, Cary, NC) to test the influence of types of containers on radiation flux density, temperature, hourly and eight hour cumulative evaporative water loss. Mean separation among containers was performed using Tukey's honest significant difference multiple comparison.

\section{Results and discussion}

LABORATORY STUDY. Container material influenced flux density, side wall, and substrate temperature (Table 1). Flux density of containers varied from $20 \mathrm{~W} \cdot \mathrm{m}^{-2}$ in Plastic and $\mathrm{FB}$ containers to about six times greater in Coir and KR containers and almost four times greater in WP containers. It was clear that container color was the major factor influencing light reflectance behavior of the container. In a study evaluating impact of white-, black-, and green-colored plastic containers

Table 1. Radiation flux density and temperature measured on the container side wall and substrate temperature at two locations following a $90 \mathrm{~min}$ exposure to a 200-W incandescent bulb at 6 inches from black plastic (plastic), keratin (KR), wood pulp (WP), fabric (FB), and Coir containers at an ambient air temperature of $20^{\circ} \mathrm{C}$ and initial substrate temperature of $18{ }^{\circ} \mathrm{C} .^{\mathrm{z}}$

\begin{tabular}{llcccc}
\hline $\begin{array}{l}\text { Container } \\
\text { type }\end{array}$ & \multicolumn{1}{c}{ Material } & $\begin{array}{c}\text { Flux density } \\
\left(\mathbf{W} \cdot \mathbf{m}^{-2}\right)^{\mathbf{z}}\end{array}$ & $\begin{array}{c}\text { Wall } \\
\text { temp }\left({ }^{\circ} \mathbf{C}\right)^{\mathbf{z}}\end{array}$ & \multicolumn{2}{c}{$\begin{array}{c}\text { Substrate temp }\left({ }^{\circ} \mathbf{C}\right) \\
\text { at } \mathbf{1} \text { inch }^{\mathbf{z}} \text { at 2 inches }\end{array}$} \\
\hline Plastic & Plastic & $20.3 \mathrm{c}^{\mathrm{y}}$ & $49.5 \mathrm{a}$ & $29.5 \mathrm{a}$ & $27.0 \mathrm{a}$ \\
KR & Chicken feather & $121.6 \mathrm{a}$ & $45.9 \mathrm{a}$ & $27.9 \mathrm{a}$ & $25.9 \mathrm{a}$ \\
WP & Wood pulp & $88.9 \mathrm{~b}$ & $41.7 \mathrm{~b}$ & $25.2 \mathrm{~b}$ & $24.6 \mathrm{~b}$ \\
FB & Recycled plastic & $19.7 \mathrm{c}$ & $47.2 \mathrm{a}$ & $22.8 \mathrm{c}$ & $21.1 \mathrm{c}$ \\
Coir & Coir fiber & $124.6 \mathrm{a}$ & $39.8 \mathrm{~b}$ & $21.7 \mathrm{c}$ & $21.2 \mathrm{c}$ \\
& Pvalue & 0.03 & 0.04 & 0.04 & 0.03 \\
\hline
\end{tabular}

${ }^{\mathrm{z}} \mathrm{l} \mathrm{W} \cdot \mathrm{m}^{-2}=0.0929 \mathrm{~W} / \mathrm{ft}^{2},\left(1.8 \times{ }^{\circ} \mathrm{C}\right)+32={ }^{\circ} \mathrm{F}, \mathrm{l}$ inch $=2.54 \mathrm{~cm}$.

${ }^{\mathrm{y}}$ Means within the same column followed by the same letter are not significantly different at $\alpha=0.05$ by Tukey's honest significant difference multiple comparison test.

Table 2. Hourly and $8 \mathrm{~h}$ cumulative evaporative water loss through container side wall and top and container side wall with top sealed obtained under a vapor pressure deficit of $2.6 \mathrm{kPa}(0.38 \mathrm{psi})$ inside an environment-controlled chamber for black plastic (Plastic), keratin (KR), wood pulp (WP), fabric (FB), and coir fiber (Coir) containers at an ambient air temperature of $20^{\circ} \mathrm{C}\left(68.0{ }^{\circ} \mathrm{F}\right)$.

\begin{tabular}{lccccc}
\hline & \multicolumn{2}{c}{ Top and side wall $(\mathrm{mL})^{\mathrm{z}}$} & & \multicolumn{2}{c}{ Side wall $(\mathrm{mL})$} \\
\cline { 2 - 3 } Container type & Hourly & Cumulative & & Hourly & Cumulative \\
\hline Plastic & $3.1 \mathrm{~d}^{\mathrm{y}}$ & $18.0 \mathrm{c}$ & & $0.3 \mathrm{c}$ & $2.6 \mathrm{c}$ \\
KR & $3.3 \mathrm{~d}$ & $18.6 \mathrm{c}$ & & $0.5 \mathrm{c}$ & $2.5 \mathrm{c}$ \\
WP & $4.2 \mathrm{c}$ & $30.5 \mathrm{~b}$ & & $3.3 \mathrm{~b}$ & $26.2 \mathrm{~b}$ \\
FB & $5.9 \mathrm{a}$ & $37.2 \mathrm{a}$ & & $3.9 \mathrm{a}$ & $32.9 \mathrm{a}$ \\
Coir & $5.0 \mathrm{~b}$ & $32.1 \mathrm{~b}$ & & $3.4 \mathrm{~b}$ & $27.8 \mathrm{~b}$ \\
$P$ value & 0.04 & 0.03 & & 0.03 & 0.03 \\
\hline
\end{tabular}

${ }^{\mathrm{z}} \mathrm{l} \mathrm{mL}=0.0338 \mathrm{fl} \mathrm{oz}$.

${ }^{y}$ Means within the same column followed by the same letter are not significantly different at $\alpha=0.05$ by Tukey's

honest significant difference multiple comparison. 
on substrate temperature, as the color became lighter more light (energy) was reflected (Markham et al., 2011).

Container wall temperature was very similar for Plastic, KR, and FB containers ranging between 45.9 and $49.5{ }^{\circ} \mathrm{C}$ (Table 1 ). Wall temperature of WP and Coir containers was $\approx 7$ to $9{ }^{\circ} \mathrm{C}$ lower than that of plastic-based containers. Substrate temperature was $20{ }^{\circ} \mathrm{C}$ at the start of the experiment. After a 90-min exposure to the heat source, substrate temperature increased $\approx 9{ }^{\circ} \mathrm{C}$ in Plastic and $\mathrm{KR}$ containers at 1 inch away from the sidewall (Table 1). In contrast, the substrate temperature increase was only 2 to $3{ }^{\circ} \mathrm{C}$ in the $\mathrm{FB}$ and Coir containers and $\approx 5{ }^{\circ} \mathrm{C}$ in WP containers. Substrate temperature at 2 inches away from the container wall increased 5 to $7^{\circ} \mathrm{C}$ in Plastic, KR, and WP containers, while there was only a $1{ }^{\circ} \mathrm{C}$ increase in the $\mathrm{FB}$ and Coir container substrates. Container wall thickness was $0.76,1.02,1.14,0.51$, and $1.1 \mathrm{~cm}$ for Plastic, KR, WP, FB, and Coir containers, respectively. Increased container wall thickness along with material properties might have contributed to the high insulation value of WP and coir containers.

Controlled environment. In a controlled environment chamber with a $\mathrm{VPD}_{\text {air }}$ of $2.6 \mathrm{kPa}$, the rigid, nonporous walls of Plastic and KR containers reduced evaporation loss of water compared with the FB and WP containers (Table 2). There was minimal water loss attributed to the side wall evaporation for Plastic and KR containers. The greatest sidewall evaporation was seen in the FB containers, while WP and Coir containers showed a lesser but significant side wall water loss compared with Plastic and KR containers (Table 2 ).

Field study. In Michigan for Aug. 2012, the average air temperature was $20.4{ }^{\circ} \mathrm{C}$ with cumulative precipitation of $49.26 \mathrm{~mm}$. Monthly mean air temperature and cumulative precipitation in August $\left(23.9^{\circ} \mathrm{C}, 3\right.$ $\mathrm{cm}$ ) were within the normal range for Lexington, KY. In Crystal Springs, MS, monthly mean air temperature was $27{ }^{\circ} \mathrm{C}$ and cumulative precipitation was $6.2 \mathrm{~cm}$ in Aug. 2012. In El Paso, TX, monthly mean air temperature in August was $29.4{ }^{\circ} \mathrm{C}$; cumulative precipitation was $0.65 \mathrm{~cm}$.

In Michigan for Aug. 2013, the average air temperature was $19.7^{\circ} \mathrm{C}$

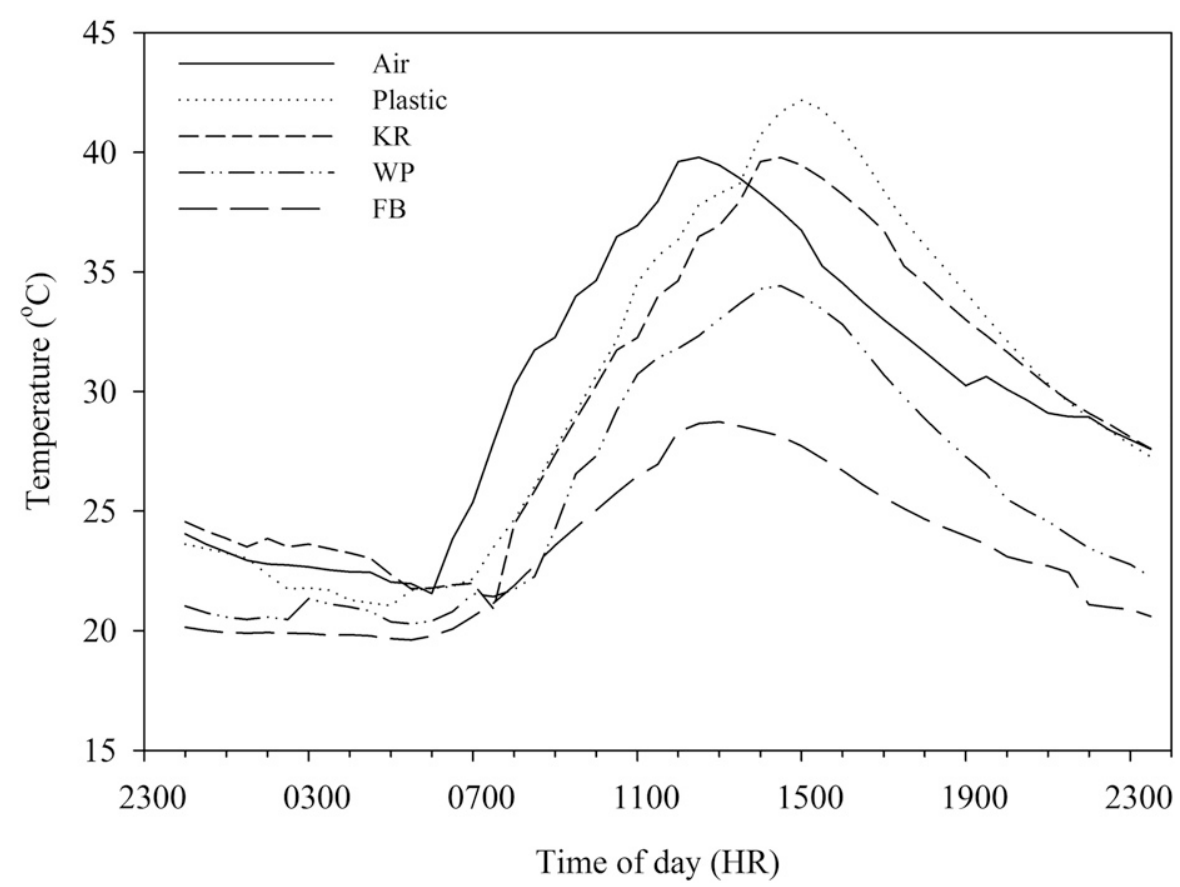

Fig. 1. Thirty-minute average substrate temperature in black plastic (Plastic), keratin (KR), wood pulp (WP), and fabric (FB) container on a full sun and nonrainy day along with corresponding air temperature in Kentucky in Aug. 2012.

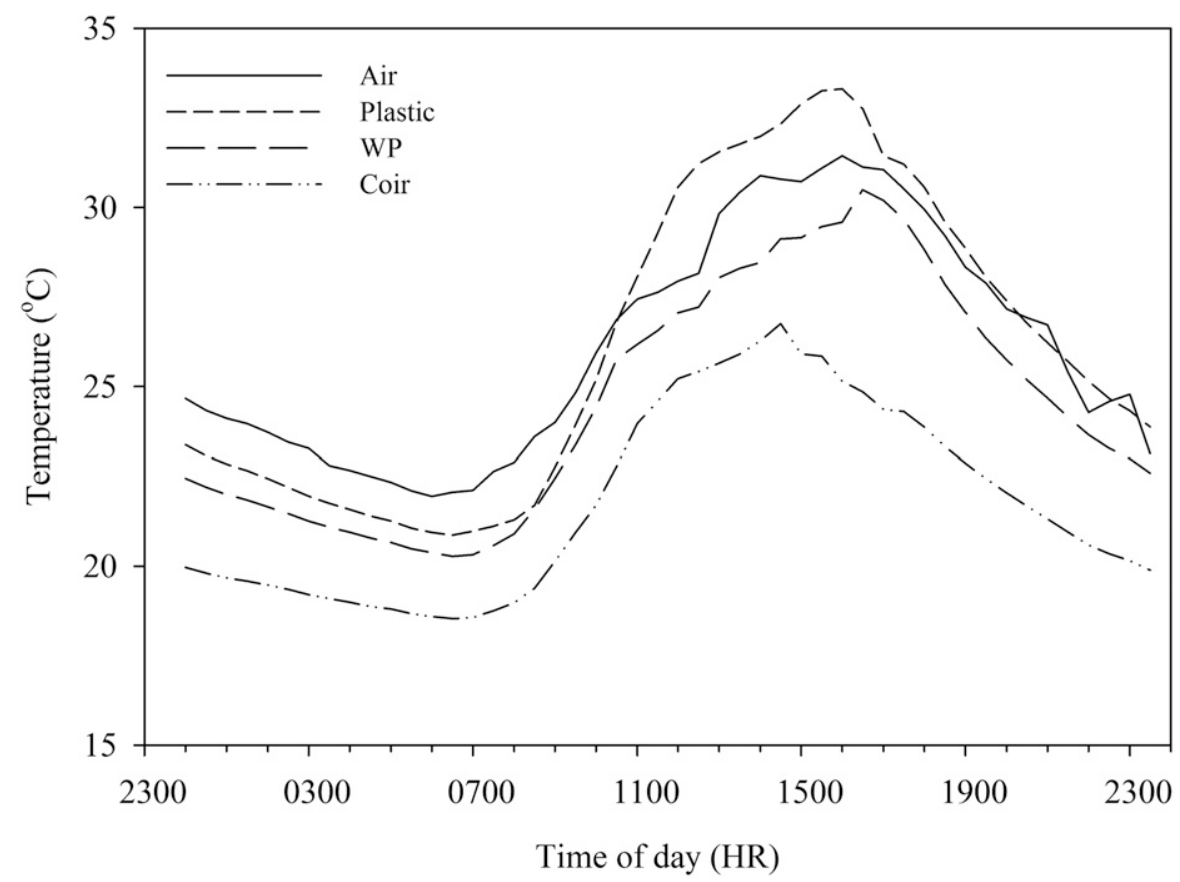

Fig. 2. Thirty-minute average substrate temperature in black plastic (Plastic), wood pulp (WP), and coir fiber (Coir) container on a full sun and non-rainy day along with corresponding air temperature in Kentucky in Aug. 2013.

with cumulative precipitation of $97.28 \mathrm{~mm}$. Monthly mean air temperature and cumulative precipitation in August were $23.1^{\circ} \mathrm{C}$ and $18.1 \mathrm{~cm}$, respectively, in Lexington, KY. In Crystal Springs, MS, monthly mean air temperature was $27{ }^{\circ} \mathrm{C}$ and cumulative precipitation was $6.2 \mathrm{~cm}$ in Aug. 2012. In El Paso, TX, monthly mean air temperature in August was $28.9{ }^{\circ} \mathrm{C}$; cumulative precipitation was $1.12 \mathrm{~cm}$.

DAILY TEMPORAL VARIATIONS OF ROOT ZONE TEMPERATURE. In the 
field, substrate temperature varied depending on the container type as demonstrated by continuous diurnal measurements on a sunny August day in Kentucky in 2012 (Fig. 1) and in 2013 (Fig. 2). Air temperature followed trends of solar radiation and increased gradually as solar radiation increased to $\approx 850 \mathrm{~W} \cdot \mathrm{m}^{-2}$ at noon. Differences in root zone temperatures between container types could be seen in the daily maxima and minima as well as in the rate of temperature change.

Averaged overall container types, Michigan had the lowest substrate temperature and Texas had the highest followed by Kentucky and Mississippi. However, all locations showed similar trends relative to substrate temperature and container type (Fig. 3) at different times of the day. Substrate temperature was generally greatest in petroleum-based Plastic containers but similar to the KR container, while substrate temperature were considerably less in WP containers and the lowest temperature gains was seen for substrate in the FB containers (Fig. 3). In 2013, Michigan observed the lowest substrate temperature across containers, while Plastic containers showed the highest temperature irrespective of location. Wood pulp containers had similar or lower temperature than Plastic and in general the lowest temperature was noticed for substrate in Coir containers (Fig. 4). An inverse trend was observed in substrate daily water loss with FB, Coir, and WP containers losing the greatest quantity of water, while Plastic and KR lost the least (Wang et al., 2015). For example, in Kentucky, the mean daily water use was highest in FB $\left(237 \mathrm{~mL} \cdot \mathrm{d}^{-1}\right)$ followed by WP $\left(219 \mathrm{~mL} \cdot \mathrm{d}^{-1}\right)$, Plastic $\left(201 \mathrm{~mL} \cdot \mathrm{d}^{-1}\right), \mathrm{KR}\left(193 \mathrm{~mL} \cdot \mathrm{d}^{-1}\right)$, and Coir $\left(209 \mathrm{~mL} \cdot \mathrm{d}^{-1}\right)$.

High substrate temperature is consistently observed in Plastic containers because the sidewalls act as an efficient heat sink to absorb radiation and conduct heat to the substrate (Martin and Ingram, 1992). The bioplastic KR containers are light yellow in color and the sidewall does not absorb as much radiation as Plastic containers, but this bioplastic is efficient in heating the substrate through conduction (Table 1; Fig. 1). Container side walls of WP absorb considerably less radiation compared with Plastic containers (Table 1) and

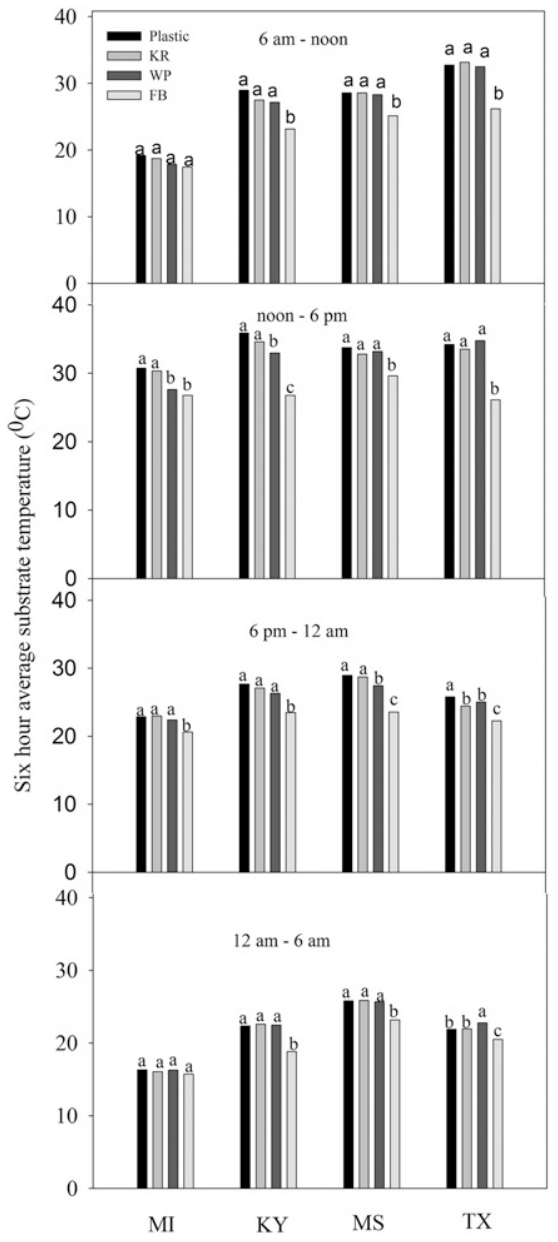

Fig. 3. Six-hour average substrate temperature in plastic (Plastic), keratin (KR), wood pulp (WP), and fabric (FB) containers during Aug. 2012 in Michigan (MI), Kentucky (KY), Mississippi (MS), and Texas (TX). In each location, same letters above bars are not significantly different among containers at $\alpha=0.05$ by Tukey's honest significant difference multiple comparison; $\left(1.8 \times{ }^{\circ} \mathrm{C}\right)+32={ }^{\circ} \mathrm{F}$.

appear to be less efficient at conducting heat to the substrate, possibly due to the lower thermal conductivity of wood insulation value of WP. The insulation value of WP-based products has been reported to be about 50 times larger than that of plastic (American Society of Heating Refrigerating and Air Conditioning Engineers, 1987) and that could have resulted in lower substrate temperature of WP. Plastic and FB containers showed similar radiation absorption because of its black coloration, but heat transfer is most likely offset by evaporative cooling from the porous sidewall material (Table 2). Evaporative cooling also appears to be a factor in reducing substrate heat buildup in WP containers relative to both Plastic and $\mathrm{KR}$ containers, which are nonporous (Table 2; Figs. 1 and 2). Similarly, Ruter (1999) attributed lower substrate temperature in WP-based paper fiber containers to evaporative cooling through porous sidewall. The afternoon substrate temperature of porous containers was lower than the air temperature indicative of evaporative cooling (Figs. 1 and 2). Faust et al. (1997) reported that about $80 \mathrm{~W} \cdot \mathrm{m}^{-2}$ of solar radiation was required to offset evaporative and thermal cooling where air and substrate temperature would be equivalent.

The negative impact of high substrate temperature on root growth has been recognized since the inception of container production (Kramer, 1949). Root zone temperature is a critical environmental factor contributing to acceptable plant growth in aboveground containers (Mathers, 2003). Substrate temperature impacts roots progressively as the temperature increases. At a temperature of $\approx 30{ }^{\circ} \mathrm{C}$, root growth slows; at $\approx 38{ }^{\circ} \mathrm{C}$, root growth and function stops (Johnson and Ingram, 1984); at temperatures 
above $40^{\circ} \mathrm{C}$ for 3 to $4 \mathrm{~h}$, root death can occur (Ingram, 1986; Ingram et al., 1986b).

In this study, critical root zone temperature where the temperature exceeded $100^{\circ} \mathrm{F}$ for more than three consecutive hours (Kramer, 1949) was used as a criterion to evaluate the potential impact of container type on substrate temperature. Critical root zone temperature was not observed at Michigan in any of the container types and was not observed at any location for FB and Coir containers (Table 3). In Kentucky, there were $11 \mathrm{~d}$ where the substrate exceeded the critical root zone temperature in Plastic and $8 \mathrm{~d}$ in $\mathrm{KR}$ containers, while the critical root zone temperature was never reached for WP containers. In Mississippi, there were $16 \mathrm{~d}$ where the substrate exceeded the critical root zone temperature in Plastic and $9 \mathrm{~d}$ in $\mathrm{KR}$ containers and $6 \mathrm{~d}$ in WP. In Texas, substrate temperature exceeded the critical root zone temperature for 21 , 9 , and $4 \mathrm{~d}$ for Plastic, $\mathrm{KR}$, and WP containers, respectively.

Plant growth. A more detailed description of plant performance in these containers across the locations is presented in Wang et al. (2015). Plant growth was generally highest for 'Green Velvet' boxwood and 'Dark Knight' bluebeard plants grown in Plastic containers across locations (Wang et al., 2015). Authors assume that early warming of Plastic containers during the day might have a beneficial effect on plants growing in black Plastic containers in Michigan. Since root zone temperature was also greatest in Plastic containers, critical root zone temperature was not the only factor determining plant growth in the different container types. One factor that might have mitigated a substrate temperature effect on growth of plants grown in Plastic and KR containers could be the twice daily irrigation provided based on daily water use. Other studies have observed that black plastic containers irrigated in the afternoon had significantly lower substrate temperatures than those irrigated predawn (Haydu and Beeson, 1997; Williamson et al., 2004).

Upon visual examination, plants grown in Plastic and KR containers showed more root growth toward the center of containers, whereas plants grown in Coir, FB, and WP showed

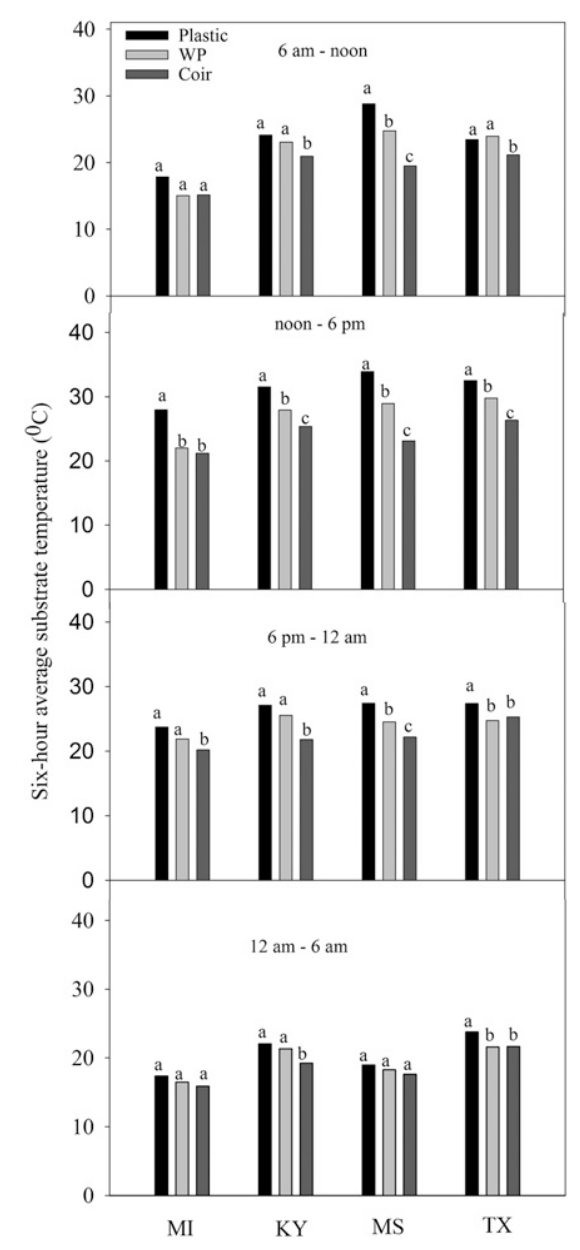

Fig. 4. Six-hour average substrate temperature in plastic (Plastic), wood pulp (WP), and coir fiber (Coir) containers during Aug. 2013 in Michigan (MI), Kentucky (KY), Mississippi (MS), and Texas (TX). In each location, same letters above bars are not significantly different among containers at $\alpha=0.05$ by Tukey's honest significant difference multiple comparison; $\left(1.8 \times{ }^{\circ} \mathrm{C}\right)+32={ }^{\circ} \mathrm{F}$.

Table 3. Critical root zone temperature [temperature exceeded $100{ }^{\circ} \mathrm{F}\left(37.7^{\circ} \mathrm{C}\right)$ at least for $3 \mathrm{~h}$ consecutive)] in black plastic (Plastic), keratin (KR), wood pulp (WP), fabric (FB), and coir fiber (Coir) containers in Michigan (MI), Kentucky (KY), Mississippi (MS), and Texas (TX).

\begin{tabular}{lcccc}
\hline \multirow{2}{*}{ Container type } & \multicolumn{4}{c}{ Time exceeding the critical root zone temp (d) } \\
\cline { 2 - 5 } & MI & KY & MS & TX \\
\hline Plastic & 0 & 11 & 16 & 21 \\
KR & 0 & 8 & 6 & 9 \\
WP & 0 & 0 & 6 & 4 \\
FB & 0 & 0 & 0 & 0 \\
Coir & 0 & 0 & 0 & 0 \\
\hline
\end{tabular}

a well-distributed, fibrous root system throughout the substrate. Apparently, the increased substrate heating reduced root growth near the sidewalls of Plastic and KR containers, but did not impact overall root biomass accumulation and plant performance. An evenly spaced root system may have a positive effect on establishment in the landscape and long-term root health.

\section{Conclusion}

The characteristics of the tested alternative container products had a marked influence on the substrate temperature. Large variations in substrate temperature were observed among the container types because of the differing thermal properties of container materials. Texas reported 
the highest and Michigan reported the lowest substrate temperature for all containers. Substrate temperatures of Plastic and KR were very close to air temperature and peaked above air temperature in hot and sunny days. The substrate temperature for porous containers: (WP, FB, and Coir) never exceeded air temperature. Additionally, substrate temperature of porous containers peaked earlier in the day than Plastic and KR containers and were cooled in the early afternoon due to evaporative water loss. The environmental benefits such as reduced landfill and enhanced sustainability of using alternative containers must be weighed against potential challenges associated with increased crop water requirements, location characteristics, and cost of containers.

\section{Literature cited}

American Society of Heating Refrigerating and Air Conditioning Engineers. 1987. Pocket guide for air conditioning, heating, ventilation and refrigeration (inch pound). Amer. Soc. Heating Refrigerating Air-Conditioning Eng., Atlanta, GA.

Beattie, D.J., R. Berghage, V. Puri, and E. Biddinger. 1987. Plant growth thrives on a high fiber diet: The pros and cons of fiber containers for nursery growing. Nursery Mgt. Production 15:81-83.

Behe, B.K., B.L. Campbell, C.R. Hall, H. Khachatryan, D.H. Dennis, and C.Y. Yue. 2013. Consumer preferences for local and sustainable plant production characteristics. HortScience 48:200-208.

Bunt, A.C. and Z.J. Kulwiec. 1970. The effect of container porosity on root environment and plant growth. I. Temperature. Plant Soil 32:65-80.

Bunt, A.C. and Z.J. Kulwiec. 1971. The effect of container porosity on root environment and plant growth. II. Water relations. Plant Soil 35:1-16.

Davidson, H., R. Mecklenburg, and C. Peterson. 1988. Nursery management administration and culture. Prentice Hall, Englewood Cliffs, NJ.

Dennis, J.L., R.G. Lopez, B.K. Behe, C.R. Hall, C. Yue, and B.L. Campbell. 2010. Sustainable production practices adopted by greenhouse and nursery plant growers. HortScience 45:1232-1237.

Evans, M.R. and D.L. Hensley. 2004. Plant growth in plastic, peat, and processed poultry feather fiber growing containers. HortScience 39:1012-1014.
Faust, J.E., R.D. Heins, and H. Shimizu. 1997. Quantifying the effect of plug-flat color on medium-surface temperatures. HortTechnology 7:387-389.

Fulcher, A., G. Niu, G. Bi, M. Evans, T. Fernandez, R. Geneve, A. Koeser, S. Nambuthiri, N. Pershey, R. Stewart, S. Verlinden, and X. Wang. 2013. Pulp or plastic. Amer. Nurseryman 2013(Feb): 20-24.

Fulcher, A., T. Steele, E. Wilkerson, R.L. Geneve, and R.S. Gates. 2011. Using transpiration chambers to detect initial transpiration in cuttings and quantify transpiration in seedlings. Acta Hort. 893:1037-1042.

Garthe, J.W. and P.D. Kowal. 1993. Recycling used agricultural plastics. Penn State Fact Sheet C-8. 15 Oct. 2013. <http://pubs.cas.psu.edu/freepubs/pdfs/ C8.pdf>.

Gosselin, A. and M.J. Trudel. 1986. Root-zone temperature effects on pepper. J. Amer. Soc. Hort. Sci. 111:220-224.

Hall, C.R., B.L. Campbell, B.K. Behe, C. Yue, R.G. Lopez, and J.H. Dennis. 2010. The appeal of biodegradable packaging to floral consumers. HortScience 45:583-591.

Haydu, J.J. and R.C. Beeson. 1997. Economic feasibility of microirrigating container grown landscape plants. J. Environ. Hort. 15:23-29.

Helgeson, M.S., W.R. Graves, D. Grewell, and G. Srinivasan. 2009. Degradation and nitrogen release of zein-based bioplastic containers. J. Environ. Hort. 27:123-127.

Ingram, D.L. 1986. Root cell membrane heat tolerance of two dwarf hollies. J. Amer. Soc. Hort. Sci. 111:270-272.

Ingram, D.L., C. Ramcharan, and T.A Nell. 1986a. Response of containergrown banana, ixora, citrus and dracaena to elevated root temperatures. HortScience 21:254-255.

Ingram, D.L., D. Webb, and H. Biggs. 1986b. Response of excised Illicium parviflorum roots to supra-optimal temperatures. Plant Soil 96:69-76.

Johnson, C.R. and D.L. Ingram. 1984. Pittisporum tobira response to container medium temperature. HortScience 19:524-525.

Jones, L.H. 1931. Effect of the structure and moisture of plant containers on the temperature of the soil contents. J. Agr. Res. 42:375-378.

Khachatryan, K., B. Campbell, C. Hall, B. Behe, C. Yue, and J. Dennis. 2014. The effects of individual environmental concerns on willingness to pay for sustainable plant attributes. HortScience 49:69-75.
Kramer, P.J. 1949. Plant and soil water relationships, McGraw Hill, New York, NY.

Lopez, R.G. and D.M. Camberato. 2011. Growth and development of 'Eckespoint Classic Red' poinsettia in biodegradable and compostable containers. HortTechnology 21:419-423.

Markham, J.W., D.J. Bremer, C.R. Boyer, and K.R. Schroeder. 2011. Effect of container color on substrate temperatures and growth of red maple and redbud. HortScience 46:721-726.

Martin, C.A. and D.L. Ingram. 1988. Root-zone temperature alters growth and survivability of ornamental trees. Proc. Southern Nursery Assn. Res. Conf. 33:64-67.

Martin, C.A. and D.L. Ingram. 1992. Simulation modeling of temperatures in root container media. J. Amer. Soc. Hort. Sci. 117:571-577.

Mathers, H.M. 2003. Summary of temperature stress issues in nursery containers and current methods of protection. HortTechnology 13:617-624.

Nambuthiri, S., A. Fulcher, A.K. Koeser, R.L. Geneve, and G. Niu. 2015. Moving toward sustainability with alternative containers for greenhouse and nursery crop production: A review and research update. HortTechnology 25:8-16.

Nambuthiri, S. and D.L. Ingram. 2014. Evaluation of plantable containers for groundcover plant production and their establishment in a landscape. HortTechnology 24:48-52.

Ruter, J.M. 1999. Fiber pots improve survival of 'Otto Luyken' laurel. Proc. Southern Nursery Assn. Res. Conf. 44:53-54.

Ruter, J.M. and D.L. Ingram. 1990. ${ }^{14}$ Carbon-labeled photosynthate partitioning in Ilex crenata 'Rotundifolia' at supraoptimal root-zone temperatures. J. Amer. Soc. Hort. Sci. 115:1008-1013.

Wang, X., R.T. Fernandez, B.M. Cregg, R. Auras, A. Fulcher, G. Niu, Y. Sun, G. Bi, S. Nambuthiri, and R.L. Geneve. 2015. Multistate evaluation of plant growth and water use in plastic and alternative nursery containers. HortTechnology 25:42-49.

Warsaw, A.L., R.T. Fernandez, and B.M. Cregg. 2009. Water conservation, growth, and water use efficiency of container-grown woody ornamentals irrigated based on daily water use. HortScience 44:1308-1318.

Williamson, C.S., S.L. Warren, and T.E. Bilderback. 2004. Timing of overhead irrigation affects growth and substrate temperature of container-grown plants. Proc. Southern Nursery Assn. Res. Conf. 49:77-80. 